\title{
Rivalry of the Elites in Ethno-Religious Conflicts: Dynamics of Conflict Arising from Territorial Split of Mamasa
}

\author{
Mohamad Subhan \\ Faculty of Social and Political Sciences \\ University of Indonesia \\ Depok, Indonesia
}

\begin{abstract}
There has been an escalating trend in social conflicts since regional autonomy came into effect. "Pemekaran daerah" which literally means territorial split or administrative fragmentation whereby new provinces and districts are created by dividing existing ones and which ironically strengthens the sense of identity based on race, ethnic group, religion, and other communal identity is one that triggers such conflicts. This study examines and discusses the rivalry of the elites in the ethno-religious conflicts that erupted during the process of territorial split of Mamasa district of West Sulawesi, Indonesia, in 2002 as a major part of regional autonomy. Mamasa,which was once part of the "mother" district of Polmas, was established into an autonomous district. Not only was the district divided but people in this region also had differing opinion on the idea of territorial split. Supporters of the administrative fragmentation were dubbed "pro" while opponents were called"kontra". This research uses qualitative method. The data were collected through in-depth interviews, field observations, and secondary data. Studies reveal that autonomy is the potential cause of conflicts because it allows for competition among the contending elites who fight for political positions, economic resources, and other aspects of power. Unlike previous literature studies that put an emphasis on political conflicts and ethnic conflicts, this research focuses on ethno-religious conflicts involving two contending ethnic groups practicing two different religions: the Mandar who are predominantly Muslims and the Toraja who are Christians. The territorial split has indeed changed the socio-political constellation in the region. The Mandar who was once the dominant ethnic group is now a minority and the Toraja have now become the dominant ethnic group in the newly-established district.
\end{abstract}

Keywords: autonomy, territorial split, conflict, elites, ethno-religious, identity politics

\section{Introduction}

The reform of 1998 is one of the key events in the history of contemporary Indonesia. After 32 years of centralistic government system under the New Order regime, the reform has led to and accelerated massive democratization. Post-reform Indonesia has adopted a more transparent and accountable political system with the central government controlling the monopolistic divisions of authority and power. The democratic transitions have changed the politics significantly. The most significant policy made during the democratic transition period is the decentralization system which is considered by many as a big bang (Hofman and Kaiser, 2002).

With the fall of the authoritarian New Order regime under president Soeharto, decentralization was inevitable. The post-reform regime accommodated the system with the issuance of Law Number 22 of 1999 concerning Local Government. It was assumed that the decentralization system was adopted to enable local people to take bigger parts in the decision-making (Hadiz, 2004: 701). In Indonesia, the term decentralization is commonly referred to as regional autonomy (Green, 2005), although some say that both terms may have different meaning because autonomy can be both territorial and non-territorial (Lyon, 2012).

The regional autonomy has indeed changed the structure of the government into a more democratic one. The manifestation of regional autonomy policy is the establishment of new districts or territorial split. As far as decentralization is concerned, the territorial split is the implementation of decentralization, or territorial decentralization to be exact(Ratnawati, 2010: 126). Terrritorial split or creation of new autonomous regions is a process of dividing an administrative region (autonomous region) into one or more new autonomous territories (Harmantyo, 2007: 16). 
Despite the fact that territorial split is frequently associated with uneven distribution of welfare and injustice within a particular administrative region, it has deepened the sense of territorial spirit unthinkable during New Order regime. Autonomy is therefore defined as ethnocentrism and communalism (Djohan, 2014: 84).

Studies conducted by Smith (2008), Peluso (2007), Bertrand (2008), and Carnegie (2009) reveal that terrritorial splits in Indonesia are prone to conflicts involving various groups who fight for political positions, economic resources, and other benefits one may reap from the creation of new province or district. While the territorial splits in many of the regions commonly led to political conflicts, economic conflicts, and ethnic conflicts; the territorial split of Mamasa district in West Sulawesi during the period of 2002-2007 led to an ethno-religious conflict involving two contending ethnic groups that practice different religion.

The serious communal conflict in Mamasa was rooted primarily in the desire of local officials for personal gain (International Crisis Group, 2005: 1). There was a fierce competiton for various political apects resulting from territorial split between two opposing factions. The "pro" faction who supported the split was the Toraja ethnic group who are Christians and those who expressed opposition to the split were the Mandar ethnic group who are Muslims (International Crisis Group, 2005: 2; Maryanah, 2013: 8; Mattulada, 2015: 323-324; Kompas, 19 October 2004).

For those reasons, this research shall discuss (1) how the elites treated the opposing factions (the "pro"and"kontra") that made them divided, and (2) how the ethno-religious identity worked in the territorial split dispute. This research also examines how the territorial split (a by-product of autonomy program) was used by the elites to bring back communal lines. History and customs played an important role in the ethno-religious conflict in Mamasa.

\section{Literature Review}

There has been an adequate number of studies focusing conflicts arising from autonomy (decentralization) program in the past few decades and especially after the reform because Indonesia is the land rife with conflicts and has been used by social scientists as their object of study (Carnegie, 2009; Smith, 2008; Peluso, 2007; Klinken, 2007; Tadjoeddin, 2002; Varshney, 2010; Aspinall, 2011; Hadiz, 2004; Bertrand, 2008/2012). Smith (2008) states that decentralization is the codification of institutional changes from an authoritarian system into a democratic one and it lays the foundation for political parties in the regions. Decentralization implementation, its form, and details of its success will politically benefit its proponents.

Peluso (2007) reiterates that forms of access and control of resources under decentralization policy determine the way an institution and individual get the benefits, costs, and claims. Fierce competition will likely take place in the regions with abundant resources. Peluso states that as is the case in other countries, Indonesia has experienced a series of violent conflicts resulting from decentralization program and more severe violent conflicts frequently break out since many parties fight for resources in the regions.

Carnegie (2009) suggests that administrative fragmentation is characterized by the presence of fortune hunters, mismanagement, incompetent government apparatus, dire public services, and marginalized local people. The territorial split generally increases the degree of homogeneity (in terms of race, ethnicity, religion, etc.) and it ironically provides "business opportunity" for local and national elites (Herawati, 2011). Bertrand (2008) states that during time of crisis, a certain group of people will take all possible measures to ensure that they are not alienated by, among others, staging violent mobilization or institutional protests demanding for an end to discrimination, greater degree of recognition, or representation.

Territorial split of Mamasa led to a prolonged conflict that caused property loss and even death (Maryanah, 2013). The motive of the conflict was not only administrative but also political identity based on ethnicity, religion, custom, and historical grievances.

The Mamasa conflict was etno-religious, the type of conflict commonly found in Nigeria. Like Indonesia, Nigeria is a post-colonial state that was once ruled by an authoritarian regime, subsequently chose democracy, and adopted decentralization system (autonomy or federalism). Abdullahi and Saka (2007) mention that Nigeria is the home to 250 ethnic groups. There are three major tribes in the country called the Fulani/Hausa in the north, Yoruba in the south and in the west, and Igbo in the east). Most of Hausa and Yoruba are Muslims while the Igbo are Christians. The largest ethnic group is very dominant while the minority is alienated. Okafor (2007) states that the ethno-religious conflicts in Nigeria are mainly due to the post-colonial socio-economic systems and political systems. 
The democratic government has allowed various ethnic groups and religious groups as well as the state to engage in fierce competition for economic and political position and the conflict is thus inevitable. The conflict has become persistent due to worsening poverty resulting from social and economic dislocations and religious and ethnic manipulation by the political elites.

\section{Theoretical Framework}

Fox (1999) states that religion is an important factor in a conflict although it has the ethnicity aspects as a whole. According to Gurr (1993), the concept of ethnicity changes over time and Horowitz (1985) views the changes through assimilation and differentiation and Fox (1999: 444) believes that religion is not merely an ethnicity aspect. Religion is an independent factor that contributes to the ethnic identity. Different religions can be an integral part of ethnic differentiation (Osaghae and Suberu, 2005).

Salawu (2010: 347) notes that an ethno-religious conflict is different from other types of social conflict because it involves various ethnic groups practicing different religions. Ethnic differences and religious differences are the determining factors of identity. Also used to describe the conflicts in Nigeria, the term ethno-religious conflict is used to refer to a conflict between ethnic identity and religious identity.

However, identity may not automatically trigger conflicts. Tilly (1978) states that a conflict breaks out because of a mobilization process of ethno-religious identity and it is not the identities that are involved in the conflict (Klinken, 2007: 108). Cruz (2000) states that ethnicity and religions do not cause conflict but they are used to mobilize support and to justify a conflict that is actually triggered by other factors such as economic and politics (Panggabean in Trijono, 2004: 52).

To describe the role of the elites in the mobilization of ethno-religious identity in Mamasa conflict, a theory of ethno-religious conflict dynamics which was established by Fox (1999) is used. According to Fox,the ethno-religious dynamics theory is more dynamic, coherent, and scientifically testable (p.443). There has been no adequate and comprehensive theory that explains how religions contribute to conflicts. Some of the theories provide dynamic explanations but include only few aspects. Other theories are comprehensive but fail to build a dynamic framework.

The ethno-religious dynamic theory explains the four basic social functions of religion: 1) religion as a meaningful framework for understanding the world, 2) providing rules and standard of behaviour that link individual actions and goals to a religious framework, 3) religion as a link between individuals and a greater whole, 4) religion's ability to legitimise actions and institutions (Fox, 1999: 446-453).

\section{Research Methods}

This research was conducted using qualitative method to examine the causes, processes, mechanism, roles of the actors, and used terminology in the ethno-religious conflict in Mamasa. The data used are the primary data collected through in-depth interviews and field observations and secondary data. This research analyzes the actors of the conflict, particularly the local elites that include the village heads, sub-district heads, prominent local figures, religious figures, political figures, and other local figures. The field observation was conducted in three sub-districts of Aralle, Tabulahan, Mambi (commonly referred to as ATM) in Mamasa district, West Sulawesi inthe period of September through October of 2015 and January through February of 2017.

\section{Results and Discussions}

Mamasa was established as an autonomous district in 2002. Its establishment and creation of Palopo city were stipulated in Law Number 11 of 2002. The new district was formerly part of Polmas district now commonly referred to a Polewali Mandar/Polman. This new district lies to the south of Mamuju district and to the west of Tana Toraja district in South Sulawesi. It also shares borders with Polman district in the south and Mamuju district and majene district in the west. It covers an area of 3,005.88 square kilometers with 17 sub-districts and 181 villages (Badan Pusat Statistik, 2017). The sub-districts are Sumarorong, Messawa, Pana, Nosu, Tabang, Mamasa, Tanduk Kalua, Balla, Sesenapadang, Tawalian, Mambi, Bambang, Buntu Malangka, Rantebulahan Timur, Mehalaan, Aralle, and Tabulahan. Mamasa is an isolated district which is geographically characterized by mountainous areas with valleys and gorges, making it difficult for infrastructure development. There is no easy access to reach this place due to serious disrepair of arterial roads for years. That was one of the major rationales to form a new district. 
Mamasa has a long and winding history before it finally became an autonomous district. During Dutch colonial period, Mamasa was part of Mandar Afdeling (1916). The afdeling (a Dutch term for district) of Mandar covered regions that were once parts of seven kingdoms along the coast of Pitu Babana Binanga (PBB) and seven kingdoms in Pitu Ulunna Salu (PUS) (Mandadung, 2008: 14). After declaration of independence, this district developed into Swapraja (self-governed region) of Kondosapata and then Kewedanaan Mamasa with Mamasa as its capital city (Mandadung, 2005: 42; Mandadung, 2008: 17).

Kewedanaan Mamasa was one of the four sub-districts under Mandar district that also included Mamuju, Majene, and Polewali. When the term "kewedanaan" was no longer used in 1959, these regions were given a district status in their own right but Mamasa and Polewali were combined into one district with its capital in Polewali. Due to "political injustice" after the district merge, the community leaders in Mamasa demanded that Kewedanaan Mamasa be separated from Polewali and become an autonomous district (Sahuding, 2008: 112).

The desire to divide the district grew stronger after the reform of 1998. The community leaders held a public meeting to discuss the creation of Mamasa district. The aspiration grew even stronger during a meeting held in Bumi Lantang Kada Nenek of Mambi sub-district on 23-24 June 1999. It was known during a district legislature meeting in 2000 that the majority of the people voiced their support for the establishment of Mamasa district (Mandadung, 2008: 39). However, representatives from three sub-districts of Aralle, Tabulahan, Mambi (popularly known as ATM) objected to the division. During a meeting in Matakali in Polmas on 20 May 2000, representatives agreed that the regions to be included in the new district were those regions which were once parts of Kewedanaan Mamasa. The regions that opposed to the creation of the new district would remain part of the "mother" district of Polmas.

The kontra figures also made a historical argument. As stated in Luyo Agreement in the 17th century, seven mountainous kingdoms (PUS) may not be separated from the seven coastal kingdoms (PBB). People of PUS believe that Mamasa is not part of PUS. People of PUS have different historical, ethnic, and religious background from those of Mamasa. The PUS people, mostly living in ATM, are Muslim Mandarwhile mamasa people are Christian Mamasa who are considered to have come from Toraja (Maryanah, 2013: 8). This is the controversial issue of Mamasa creation.

\section{Rivalry of the Elites: A Fight for Power, Polarization, and Government Dualism}

Hadiz (2005: 241) states that autonomy concerns not only with the technical issues of government system but also fierce competition among the elites who fight for resources. Autonomy is about a basic issue of competing for power. The competition for resources involves local players who were marginalized during the New Order regime (Hadiz, 2005: 244-245).

This research finds that rivalry of the elites contributes to Mamasa conflict. This is possiblebecause the elites have the access to politics and resources (Hartmann, 2007). They have high positions in the community and control of the society with their social and political power (Christensen, 2013; Ost, 2004; Zatterberg, 1968).

In Mamasa context, the elites are both local and national. The national elites are those members of House of Representatives who fight for political aspects in the region while local elites are the local government executives at the village, sub-district, district and provincial levels, local political party elites, local community figures, such as religious figures, education figures and youth leaders, and other figures"putra daerah"(son of the soil) that have strong ties with Mamasa due to family ties, place of birth, and length of domicile.

Higley (2008) defines the elites as persons who are able, by virtue of their authoritative poitions in powerful organizations and movements, to affect political outcomes regularly and substantially. The elites are the key actors. The rivalry of the elites in Mamasa district creation had divided the people in the district into two: those supporting the sub-division known as "pro" and those who opposed it, known as "kontra".

Elites and social class are interrelated (Vergara, 2013: 33). The contending elites built their bases within the society. With their high status, authority, and legitimation, the elites were able to strongly exert their influence within the grassroots. The local elites have strong influences in the villages. In a patronage culture, the community consider the elites as their role models. Each of the elite groups gained support from the community, making them polarized and the conflict subsequently rocked the ATM region. The kontra used the historic symbols of PUS imperium. This group included Ikatan Keluarga Pitu Ulunna Salu (IKPUS), Forum Komunikasi Masyarakat Pitu Ulunna Salu (FOKMAPUS),Kesatuan Pelajar Mahasiswa Polewali Mamasa Mandar (KPM-PMM),Forum Pemuda dan Mahasiswa Pitu Ulunna Salu, also Forum Kepala Desa/Lurah ATM-PUS. 
Forum Peduli Nasib Aralle Tabulahan Mambi (FPN-ATM), and other student organizations, such as Aliansi Pemuda Pelajar Aralle Tabulahan Mambi (APPM-ATM), Ikatan Pemuda Pelajar Mahasiswa Bujung Manurung (IPPM-BM), Ikatan Pemuda Pelajar Mahasiswa Asal Lokal (IPPMAL), Ikatan Pemuda Pelajar Mahasiswa Saluassing (IPPMS). The opposing group, known as Masse Bambangan, were the residents of Bambang, Rantebulahan Timur, and Buntu Malangka sub-districts.

The dispute between the two groups had divided the region. The residents of sub-districts located in the east and north sides, such as Bambang Buda, Bambang, and Buntu Malangka were the pro. The residents of sub-districts located in the western part of the district, such as Mambi, Rantebulahan, Aralle were the kontra. With the community being polarized and the territory being segregated, the conflict lasted from 2002 to 2006 resulting in deaths, destroyed houses, intimidation, tortures, and massive exodus.

Snyder (2000) warns that a country is prone to communal conflicts at the early stage of its democratization process (Tadjoeddin, 2002: 14). The administrative sub-division of ATM as a by-product of decentralization has resulted in a bleak history of autonomy. Klinken (2007: 4) states that communal violence is a form of violence that is perpetrated across ethnic or religious lines. In quantity, communal violence is more common than any other social unrests. The communal violence in Mamasa was a conflict between the "pro" and "kontra".

The conflict between the two factions had escalated because the conflict itselt was also the representation of conflict between the "mother" district and the newly-established district. The government of the two districts openly expressed their support for each of the the contending parties. The government of Polmas ditrict was with the kontra while the government of Mamasa gave their full support for the pro. The rivalry between the two parties had brought chaos to the government system. The government was divided (government dualism).There were both representative of Polmas and Mamasa in ATM. One village had two village heads. One sub-district was led by two sub-district heads. The government could not perform effectively and the public services were disrupted.

\section{Landscape of Ethno-Religious Demography}

One can understand the nature of Mamasa conflict from its history and ethnic rivalry. This research finds that the conflict resulting from territorial split has led to politicization of ethno-religious identity. Salawu (2010: 346) defines ethno-religious conflict as a situation whereby a multi-ethnic and multi-religion community is characterized by hostilities, prejudice, fear, and violent-prone attitudes. There was once a territorial split in Nigeria. The people in the northern part of the district are Muslims who dominated the politics while those living in the southern side are Christians who controlled the economy.

The nature of conflict in Nigeria, such as polarization of its people and ethno-religious segregation, is similar to that in Mamasa. There are two dominant ethnic groups in Mamasa: Mandar and Toraja. Other ethnic groups include Bugis, Makassar, andJavanese (Mattulada, 2015: 324). The Mandar and Torajan speak different language, practice different customs, and have different history (George, 1996: 27). The Mandar live in the western part of the district separated by Mamasa River and stretching as far as west coast. This region used to be part of the seven kingdoms of Pitu Ulunna Salu (PUS) and it is the reason why the people are referred to as PUS people, the Mandar sub-ethnic. The Mandar are predominantly Muslims.

The Torajan live in the region east of Mamasa River that stretches through the border line of Tana Toraja district of South Sulawesi province. The Torajan are the biggest ethnic group in Mamasa. They call themselves Mamasa or Toraja Mamasa, a Toraja sub-ethnic. The Torajan are predominantly Christians. Some of them still practice the religion of their anchestors calledaluk tomatuaorada' mappurondo. The people practicing this religion are accepted by the Christians but not by Muslims. In terms of ethnic and religious distribution, Mamasa district can be divided according to the "ethno-religious demographic lines". The zonal system indicates that the "Muslim-Mandar territorial" hegemony is in the western part of district while the "Christian-Torajan territorial" hegemony is in the eastern part of the district.

\section{Politicization of Ethno-Religious Identity}

The ethno-religious composition and demographic landscape are the two key issues of Mamasa conflict. The ethno-religious identity was politicized and the conflict had shifted to ethno-religious conflict.The conflict between the pro and kontra was the representation of conflict between Christian-Torajan (the Mamasa people) and Muslim-Mandar (the PUS people). The politicization of ethno-religious identity was due to the shift in power domination of the majority and minority. 
Prior to territorial split, the Muslim-Mandar were the majority. The Mandar population was 231,478 (51.8\%), while the population of Torajan was 106,450 (23.8\%). After the separation of Mamasa district from Polmas district, the ethnic composition changed. The population of Mandar in new Mamasa was only 8,231 (7,0\%), while the population of Torajan was 100,648 $(85,2 \%)$ (See Figure 1).

\section{Figure 1 - Ethnic Composition}

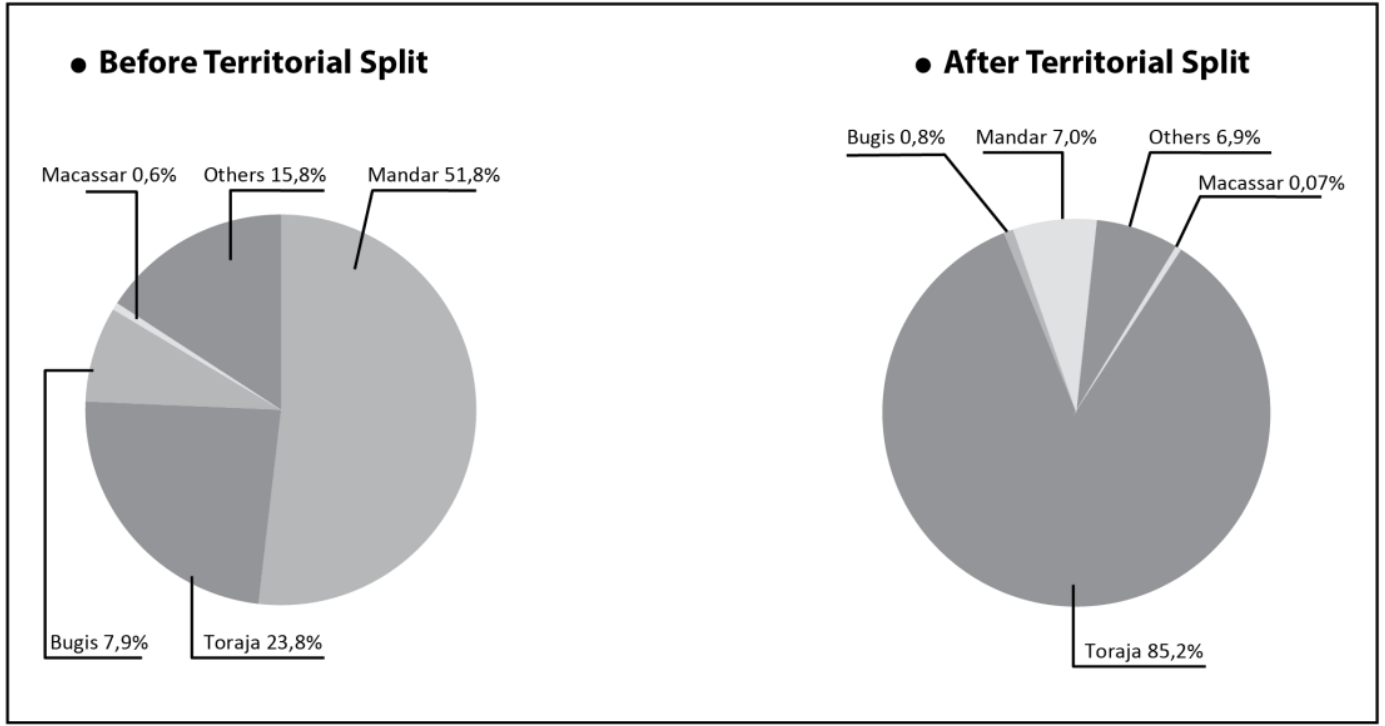

Source: data based on BPS (2000)

A change in religious composition also took place. Prior to territorial split, the number of Muslims was 347,133 (77.7\%). The number included the Muslims from other ethnic groups, such as Bugis (7.9\%), Makassar $(0.7 \%)$, Luwu, Javanese, Duri, Selayar (15.8\%). The number of Christians was 91,278 or $20.4 \%$. After the administrative sub-division, the number of Muslims had declined to 24,534 (20.8\%) while the number of Christians was 85,370 (72.3\%) (See Figure 2).

Figure 2 - Religious Composition

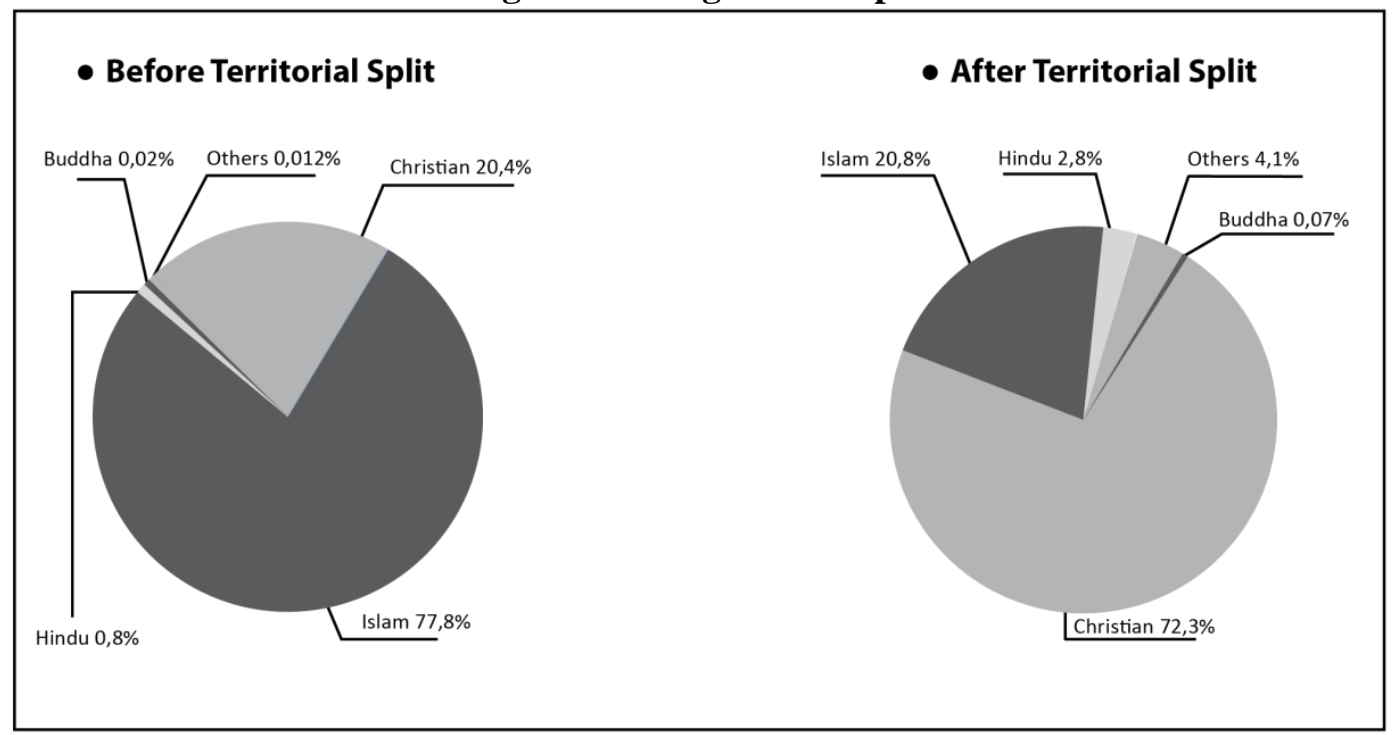

Source: data based on BPS (2000)

The administrative sub-division in Mamasa has changed the demography significantly. The Muslim Mandar who were once the majority has now become the minority while the Christian-Torajan who were once a minority has now become the majority. In this context, the Muslim-Mandar suspected that the territorial split was part of the Christian mission. The ethno-religious sentiment spread fast, especially among those people living in a highly homegeneous inland terrritory. 
The politicization of ethno-religious identity was so obvious in Mamasa conflict. Cruz (2000) states that ethnicity and religions do not cause conflict but they are used to mobilize support and to justify a conflict that is actually triggered by other factors such as economic and politics (Panggabean in Trijono, 2004: 52.This is in line with Osaghae and Suberu (2005) who propose a fact that the difference in culture, tradition, religion, and ethnicity in a country never trigger conflicts but the conflict erupts due to politicization of identity (Abdulahi and Saka, 2007).

The two ethnic groups are poles apart in terms of belief system, tradition, and way of life. Islamic dietary law forbids muslims to eat pork but pigs are parts of rituals and tradition of the people of Mamasa. The animal is also used for offerings to their gods. Swine in this district is the symbol of prosperity, wealth, health, and long life (Buijs, 2008: 111). They also perform a ritual called paisuamwhere pigs are slaughtered before being sacrified to the spirits (Mandadung, 2005: 52-53).

They also have different funeral ceremony. In Islam, the dead must be immediately buried. In contrast, the people of Mamasa perform a funeral ritual called rambu solo'. The preparation for the ceremony takes a long time and costs a lot of money. The ritual begins with the slaughter of sacrifice animals, commonly pigs and buffaloes depending on the social status of the dead and his/her family.

The funeral in Mamasa (and in Tana Toraja, South Sulawesi) is an important ritual. They must prepare everything, including funds, for a funeral. The people of Mamasa have different ways of treating the departed. The pre-Christian tradition of the Mamasa people requires that the dead be laid in a wooden casket.

With the contrasting traditions, rituals, and religion, the two ethnic groups are prone to ethno-religious politicization. The historical grievance, the Dutch colonial government with their Christian mission and guerrillas of Darul Islam (DI/TII) rebellion in 1950s-1960s, also plays a part. The PUS people living in ATM consider the Christian of Mamasa are the product of Dutch colonial government. The people of Mamasa, on the other hand, have a suspicion that the PUS in ATM are the supporters of DI/TII rebels. The history of violence is a lasting scar and a stain on Muslim-Christian relation in Mamasa.

\section{Conclusion}

The territorial split of Mamasa should be a valuable input for better implementation of regional autonomy after the reform. The administrative sub-division ironically sparked conflict of interest involving local elites. The creation of Mamasa district which was initially aimed at minimizing economic gaps and injustice and promoting the well-being of the people, has sparked conflicts that may jeopardize the regional autonomy.

This research finds that the elites have a vital role in the conflict resulting from territorial split. The competition among elites who fight for power in the newly-established autonomous district by using the sentiment of ethno-religious identity has changed the constellation of socio-political hegemony and domination in Mamasa. The Muslim-Mandar have lost their hegemony while the Christian-Toraja have gained greater portion of hegemony.

As a result, the Muslim-Mandar (the PUS people) voiced their opposition to the territorial split which they consider part of Christian mission. Fox (1999) states that when a religious framework is challenged, the response will be the defensive action that is prone to conflict. This is due to the fact that religion is a belief system that organizes adherents to the values, has standards and norms, builds cohesiveness among its followers, and legitimate the actors.

\section{References}

Abdullahi, Ali Arazeem and Saka L. (2007). "Ethno-Religious and Political Conflicts: Threat to Nigeria Nascent Democracy".Journal of Sustainable Development in Africa. Volume 9, No.3, 2007.

Aspinall, Edward. (2011). "Democratization and Ethnic Politics in Indonesia: Nine Theses". Journal of East Asian Studies, May-August 2011, Vol 11, No 2.

Badan Pusat Statistik Provinsi Sulawesi Selatan. (2000). Karakteristik Penduduk Kabupaten Polewali Mamasa: Hasil Sensus Penduduk 2000.

Badan Pusat Statistik Kabupaten Mamasa. (2017). Kabupaten Mamasa dalam Angka.

Bertrand, Jacques. (2008). "Ethnics Conflicts in Indonesia: National Models, Critical Junctures, and the Timing of Violence".Journal of East Asian Studies, Vol. 8, No. 3(Special Issue: Collective Violence in Indonesia, September-December 2008). 
-------. (2012). Nasionalisme dan Konflik Etnis di Indonesia (Nationalism and Ethnic Conflict in Indonesia).Translated by Achmad Munjid. Yogyakarta: Ombak Publishing.

Buijs, Kees. (2009). Kuasa Berkat dari Belantara dan Langit, Struktur dan Transformasi Agama Orang Toraja di Mamasa Sulawesi Barat (Power of Blessing from the Wilderness and from Heaven: Structures and Transformations in the Religion of the Toraja in the Mamasa Area of South Sulawesi). Translated by Ronald Arulangi. Jakarta-Makassar: Ininnawa and KITLV.

Carnegie, Paul J. (2009). "Democratization and Decentralization in Post-Soeharto Indonesia: Understanding Transition Dynamics". Pacific Affairs Vol. 81, No 4. University of British Columbia.

Christensen, Michael. (2013). "The Social Facts of Democracy: Science Meets Politics with Mosca, Pareto Michels, and Schumpeter".Journal of Classical Sociology.

Djohan, Djohermansyah.(2014).Merajut Otonomi Daerah Pada era Reformasi (Kasus Indonesia), Ikatan Keluarga Alumni Pendidikan Tinggi Kepamongprajaan (IKAPTK), Jakarta.

Fox, Jonathan. (1999). "Towards a Dynamic Theory of Ethno-religious Conflict". Jurnal Nations and Nationalism 5 (4), 1999, p. 431-463.

George, Kenneth M. (1996). Showing Sign of Violence: The Cultural Politics of a Twentieth-Century Headhunting Ritual, Berkeley-Los Angeles-Oxford, University of California.

Green, Keith.(2005).Decentralization and Good Governance: The Case of Indonesia, Munich Personal RePEc Archive (MPRA) paper No 18097, posted 26 October 2009, online at http://mpra.ub.uni-muenchen.de/18097.

Hadiz, Vedi R. (2004). "Decentralization and Democracy in Indonesia: A Critique of Neo-Institutionalist Perspective".Development and Change 35, Oxford and Malden: Blackwell Publishing. . (2005). Dinamika Kekuasaan: Ekonomi Politik Indonesia Pasca-Soeharto. Jakarta: LP3ES.

Harmantyo, Djoko. (2011).Desentralisasi, Otonomi, Pemekaran Daerah dan Pola Perkembangan Wilayah di Indonesia, paper presented at National Conference in Bali on October 2011.http://geografi.ui.ac.id/portal/sivitas-geografi/dosen/makalah-seminar/496-2/.

Hartmann, Michael.(2004).The Sociology of Elites, London and New York: Routledge Taylor and Francis Group.

Herawati, Nunik Retno Herwati. (2011). "Pemekaran Daerah di Indonesia”.Politika: Jurnal Ilmu Politik, Vol 2, No 1, 2011, p 57-65, Universitas Diponegoro Semarang.

Higley, John. (2008). Elite Theory in Political Socilogy.

Hofman, Bert and Kai Kaiser.(2002).The Making of the Big Bang and its Aftermath: A Political Economy Perspective, Paper Presented at the Conference: Can Decentralization Help Rebuild Indonesia? A Conference Sponsored by the International Studies Program, Andrew Young School of Policy Studies, Georgia State University, Atlanta.

International Crisis Group. (2005). Decentralisation and and Conflict in Indonesia: The Mamasa Case, Asia Briefing No 37, Singapore/Brussels, 3 May 2005.

Klinken, Gerry van.(2007). Perang Kota Kecil: Kekerasan Komunal dan Demokratisasi di Indonesia. Translatd by Bernard Hidayat. Jakarta: KITLV dan Yayasan Obor Indonesia.

Kompas, 19 October 2004.

Lyon, Aisling. (2012). "Between the Integration and Accomodation of Ethnic Difference: Decentralization in the Republik of Macedonia". Journal of Ethnopolitics and Minority Issues in Europe. Vol 11, No. 3, 2012, 80-103.

Mandadung, Arianus. 2005. Keunikan Budaya Pitu Ulunna Salu Kondosapata Mamasa, Mamasa: Cooperation Arianus Mandadung and Mamasa Government.

--------. (2008). Sejarah Terbentuknya Kabupaten Mamasa.

Maryanah, Tabah. (2013). "Governance dalam Manajemen Konflik Pemekaran Kabupaten Mamasa". Jurnal Ilmiah Administrasi Publik dan Pembangunan, Vol. 4 No 1, January-June 2013.

Mattulada, M Thamrin. (2015). "Primordialisme yang Tersembunyi: Dinamika Pemekaran Sulawesi Barat dari Sulawesi Selatan pada 2004”. Jurnal Walasuji, Vol. 6, No 2, 315-326, December 2015.

Okafor, Emeka Emmanuel.(2007). "Sociological Implications of Communal and Ethno-Religious Clashes in New Democratic Nigeria". Stud. Tribes Tribals, 5(1): 35-45 (2007).

Osaghae, Eghosa $\mathrm{E}$ and Rotimi T Suberu.(2005).A History of Identities, Violence, and Stability in Nigeria. Crise Working paper No 6 (January 2005). 
Ost, David. "Politics as the Mobilization of Anger: Emotions in Movements and in Power".European Journal of Social Theory 7. London-New Delhi.

Peluso, Nancy.(2007). "Violence, Decentralization, and Resource Access in Indonesia", Peace Review: A Journal of Social Justice, Volume 19, Issue 1, 2007.

Ratnawati, Tri. (2010). "Satu Dasawarsa Pemekaran Daerah Era Reformasi: Kegagalan Otonomi Daerah?".Jurnal Ilmu Politik, $21^{\text {st }}$ edition.

Sahuding, Sarman. (2008). PUS \& PBB dalam Imperium Sejarah: Sejarah dan Kearifan Rakyat Sulawesi Barat, Salah Satu Warisan sastra dan Kebudayaan Indonesia. Makassar: Murimuri Transmedia.

Salawu, B. (2010). 'Ethno-Religious Conflicts in Nigeria: Causal Analysis and Proposals for New Management Strategies". European Journal of Social Sciences - Volume 13, Number 3 (2010).

Smith, Benjamin. (2008). "The Origins of Regional Autonomy in Indonesia: Experts and the Marketing of Political Interests".Journal of East Asian Studies, Vol. 8, No. 2 (May-August 2008).

Tadjoedin, Mohammad Zulfan. (2002).Anatomi Kekerasan Sosial dalam Konteks Transisi: Kasus Indonesia 1990-2001, United Nations Support Facility for Indonesian Recovery (UNSFIR), Proyek INS/99/002 Policy Support for Suistainable Social Economic Recovery. April 2002. Jakarta.

Trijono, Lambang (ed). (2004). The Making of Ethnic \& Religious Conflicts in Southeast Asia: Cases and Resolutions. Centre for Security and Peace Studies Universitas Gadjah Mada, Yogyakarta.

Varshney, Ashutosh (ed). (2010). Collective Violence in Indonesia. Lynne Rienner Publishers, Boulder.

Vergara, Luis Garrido. (2013). "Elites, Political Elites and Social Change in Modern Societies", Revista de Sociologia, No 28, page 31-49.

Zetterberg, Hans L.(1968).Elites: Vilfredo Pareto, This is Chapter 3 of the web-publication, European Proponents of Sociology Prior To World War I, Swedish version available in Sociologis följeslagare (Ratio, Stockholm 1993), Bedminster Press. 